\title{
Ensiled slaughter offal as a protein source for growing pigs
}

\author{
KIRSI PARTANEN, TIMO AlaVIUHKOLA and MatTI NÄSI
}

Partanen, K., Alaviuhiol.a, T. \& NÄsı, M. 1992. Ensiled slaughter offal as a protein source for growing pigs.Agric. Sci. Finl. 1: 547-558. (Univ. Helsinki, Dept. Anim. Sci., SF-00014 University of Helsinki and Agric. Res. Centre of Finland, Swine Res. Sta., SF-05840 Hyvinkää, Finland.)

The present study was conducted in order to evaluate the use of slaughter offal preserved by lactic acid fermentation in pig diets. Offal was first ground, autoclaved, and mixed with $70 \mathrm{~kg}$ sugar beet molasses per $1000 \mathrm{~kg}$. After that it was inoculated with $2 \times 105$ lactic acid bacteria/g and incubated at $35^{\circ} \mathrm{C}$ for three days. The final $\mathrm{pH}$ of the fermented product was 3.80. The ensiled slaughter offal (ESO) contained $239 \mathrm{~g}$ dry matter (DM) $/ \mathrm{kg}$, and $319 \mathrm{~g}$ crude protein (CP) and $403 \mathrm{~g}$ crude fat (CF)/kg DM. CP contained $47 \mathrm{~g}$ lysine, $33 \mathrm{~g}$ threonine, $16 \mathrm{~g}$ methionine, and $8 \mathrm{~g}$ cystine $/ \mathrm{kg}$.

A digestibility and nitrogen $(\mathrm{N})$ balance assay was conducted with eight barrows using a $2 \times 4$ factorial arrangement in a $8 \times 4$ cyclic change-over design. The factors were protein source and protein level. Barley-based diets were supplemented with increasing levels $(0,20,40$, and $60 \mathrm{~g} \mathrm{CP} / \mathrm{kg})$ of ESO or soyabean meal (SBM).

Increasing the protein supply led to a linear increase in the digestibility of $\mathrm{CP}$ $(\mathrm{p}<0.001)$ and a quadratic increase in the digestibility of $\mathrm{CF}(\mathrm{p}<0.001)$. The apparent digestibility of organic matter, $\mathrm{CP}$, and $\mathrm{CF}$ calculated by the regression method was $0.811,0.898$, and 0.789 for ESO and $0.849,0.867$, and 0.731 for SBM, respectively. $\mathrm{N}$ retention increased linearly with increasing protein supply $(\mathrm{p}<0.001)$, but no significant differences were observed between protein sources. Although the amount of $\mathrm{N}$ excreted in urine was higher $(\mathrm{p}<0.05)$ for ESO- than SBM- supplemented diets, there were no significant differences in urea- $\mathrm{N}$ excretion between protein sources. The daily weight gain increased linearly with increasing protein supplementation $(\mathrm{p}<0.001)$ and was higher for SBM- than for ESO-supplemented diets ( $\mathrm{p}<0.05$ ).

A growth trial was conducted with 216 pigs using a randomized complete block design. No significant differences were observed in growth performance, feed consumption, or feed conversion rate between the control diet and the test diet. ESO provided 0.20 of DM and 0.22 of feed units of the test diet. Carcass weight and thickness of both back and side fat were similar on both treatments $(\mathrm{p}>0.05)$, whereas dressing percentage was higher in pigs fed the test diet $(\mathrm{p}<0.01)$. No significant differences were found in the chemical composition or organoleptic scores of the longissimus dorsi muscle between the treatments.

Key words: slaughter offal, lactic acid bacteria, preservation, digestibility, performance, pigs 


\section{Introduction}

Fur animal production in Finland has decreased sharply in recent years causing a considerable decline in the demand of fresh slaughter offal for fur animal feed. Consequently, increasing amounts of slaughter offal have been dried to meat and bone meal, which has potential as an important protein source in pig diets because of its high protein content. However, the proportion of meat and bone meal is often limited to $0.05-0.07$ in the diets of growing pigs due to its high ash content, poor quality of protein, and large variability in the overall composition and availability of nutrients. For example, a European survey of 124 samples showed that ash content ranged from 52 to $442 \mathrm{~g} / \mathrm{kg}$ dry matter (DM), crude protein (CP) from 344 to 738 $\mathrm{g} / \mathrm{kg}$ DM and lysine from 29 to $70 \mathrm{~g} / \mathrm{kg} \mathrm{CP}$ (BRUYER et al. 1990). The wide range in nutrient content reflects variations in the proportions of bone, collagen and soft tissue in the raw material. The protein of soft tissue is highly digestible with a more desirable amino acid profile, whereas the protein of bone and collagen is difficult to digest and has a poorer amino acid profile, despite the high protein content. Danish experiments have shown that the ash content of meat and bone meal is a good indicator of apparent digestibility of the protein, amino acid composition, and energy value. All these properties deteriorate with increasing ash content (JUST et al. 1982). Thus, the exclusion of bone from the raw material could effectively improve the nutritional quality of the meal.

The processing method, particularly excessive heating, is an important factor affecting the quality of protein in the meal. In the drying process, high temperatures are needed to reduce the high moisture content of offal, as well as to kill pathogenic microbes. It has been shown that intense drying , applying a high temperature and pressure, reduces the digestibility of nitrogen and the availability of amino acids considerably (BATTERHAM et al. 1986, KNABE et al. 1989). It has been suggested that amino acids may react with other compounds dur-

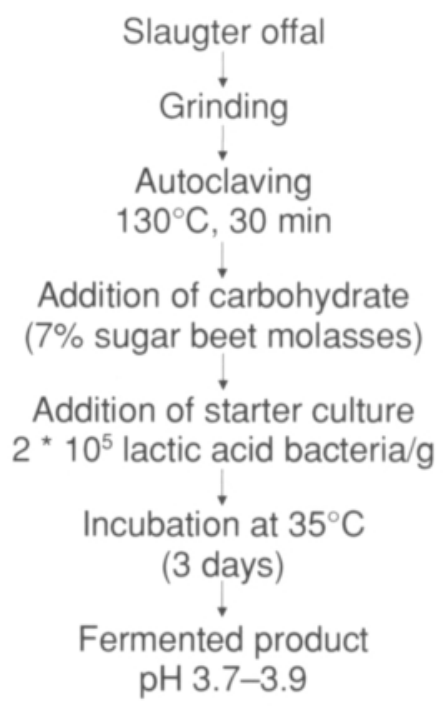

Fig. 1. Process of ensiling slaughter offal.

ing the heating process, resulting in chemically modified amino acids. These modified amino acids may have a decreased digestibility and absorption generally, or they may be absorbed in forms that are utilized inefficiently (BATTERHAM et al. 1990, Moughan 1991).

Because of the negative effects of drying on the quality of protein in slaughter wastes, continuous attempts have been made to find alternative preservation methods to obtain animal feed ingredients with a high nutritive value and hygienic quality. Recently, more interest has been shown towards preservation using organic acids and lactic acid fermentation. Studies have indicated that lactic acid fermentation is suitable for the preservation of poultry offal (TiBBETTS et al. 1987, RUSSELL et al. 1992) as well as cattle and swine offal (SKREDE and NES 1988). Because of its high moisture content, slaughter offal is very susceptible to deterioration caused by bacteria and endogenous enzymes released from animal tissue. Thus, if the offal is fermented with lactic acid bacteria, it is necessary to add fermentable carbohydrates to ensure a rapid drop of $\mathrm{pH}$ below 4.0 (RUSSELL et al. 1992). The offal may also contain dangerous pathogens and is, therefore, considered an environmental contam- 
Table 1. Composition of diets in Experiment 1.

\begin{tabular}{|c|c|c|c|c|c|c|c|c|}
\hline Diet & 1 & 2 & 3 & 4 & 5 & 6 & 7 & 8 \\
\hline Protein supplement & ESO-0 & ESO-20 & ESO-40 & ESO-60 & SBM-0 & SBM-20 & SBM-40 & SBM-60 \\
\hline $\mathrm{CP}, \mathrm{g} / \mathrm{kg} \mathrm{DM}$ & 105 & 125 & 145 & 165 & 105 & 125 & 145 & 165 \\
\hline Barley DM, g/kg & 800 & 800 & 800 & 800 & 800 & 800 & 800 & 800 \\
\hline Barley starch DM, g/kg & 200 & 134 & 68 & 2 & 200 & 160 & 120 & 80 \\
\hline Ensiled slaughter offal DM, g/kg & 0 & 66 & 132 & 198 & - & - & - & - \\
\hline Soyabean meal DM, g/kg & - & - & - & - & 0 & 40 & 80 & 120 \\
\hline
\end{tabular}

ESO $=$ ensiled slaughter offal, $\mathrm{SBM}=$ soyabean meal

inant. However, it has been shown that fermentation with lactic acid bacteria destroys certain pathogenic bacteria and viruses (WOOLEY et al. 1981, SHOTTS et al. 1984).

This study was conducted to evaluate the nutritive value of slaughter offal, ensiled with sugar beet molasses and lactic acid bacteria, for growing pigs.

\section{Material and methods}

\section{Ensiling of slaughter offal}

Fresh slaughter offal, consisting mainly of internal organs and digestive tracts of slaughtered cattle, was collected from an abattoir, and then ground and autoclaved at $130^{\circ} \mathrm{C}$ for 30 minutes. After autoclaving, part of the fat was mechanically removed from the surface and sugar beet molasses was added to the hot offal $(70 \mathrm{~kg}$ per $1000 \mathrm{~kg}$ ). This mixture was cooled down to $35^{\circ} \mathrm{C}$ and a commercial lactic acid bacteria culture (Medipharm Stabisil, 20*109 lactic acid bacteria/g) was added at a rate of $10 \mathrm{~g}$ per $1000 \mathrm{~kg}$ to give $2 \times 105$ lactic acid bacteria/g. The offal was then fermented in anaerobic silos for three days. The ensiling process is shown in Figure 1. The ensiled slaughter offal (ESO) was manufactured by Ab Feora Oy in Uusikaarlepyy.

The ESO used in Experiment 1 was frozen after three days of fermentation to ensure the homogenous composition of the feed throughout the trial. In Experiment 2, the ESO was transported weekly to the farm and stored in covered plastic containers.

\section{Animals, diets and experimental procedures}

\section{Experiment 1}

A digestibility and nitrogen $(\mathrm{N})$ balance assay was conducted with eight Large White $x$ Landrace barrows using a $2 \times 4$ factorial arrangement in a $8 \times 4$ cyclic change-over design to compare ESO and soyabean meal (SBM) as a protein supplement for growing pigs. The pigs were kept in metabolism cages throughout the trial, which allowed separate quantitative collection of urine and faeces. Each period comprised five days of adjustment and five days of collection. The live weight of the pigs was $41 \mathrm{~kg}$ at the beginning and $71 \mathrm{~kg}$ at the end of the trial. The average weight gain was $730 \mathrm{~g} / \mathrm{d}$.

The experimental diets consisted of a fixed amount of barley and an increasing amount of ESO or SBM $(0,20,40$ and $60 \mathrm{~g}$ supplemented $\mathrm{CP} / \mathrm{kg}$ DM). The diets were adjusted by barley starch to give the same amount of dry matter per day. The composition of the experimental diets is shown in Table 1 . The daily ration was 1.8, 2.0, 2.2 and 2.4 $\mathrm{kg} \mathrm{DM} / \mathrm{pig} / \mathrm{d}$ in periods 1 to 4 , respectively. The pigs were given $40 \mathrm{~g}$ mineral and vitamin mixture (Seleeni-Minera) and 18-30 g calcium carbonate/d based on live weight to meet the mineral and vitamin requirements (SALO et al. 1990).

\section{Experiment 2}

A growth trial was conducted in a commercial piggery with 224 cross bred pigs using a randomized complete block design. Due to the size of the pig- 
gery, the trial was conducted in two blocks of 112 animals. Eight pigs (four gilts and four barrows) were placed into each pen and the pens were randomly allotted to two treatments.

The control pigs were fed a diet consisting of 700 $\mathrm{g}$ barley, $150 \mathrm{~g}$ oats and $150 \mathrm{~g}$ protein concentrate (Sian-Herkku S -tiiviste, $400 \mathrm{~g} \mathrm{CP} / \mathrm{kg}$ ) per $\mathrm{kg}$. The test pigs were fed ESO and a feed mixture, which consisted of $700 \mathrm{~g}$ barley, $190 \mathrm{~g}$ oats, $65 \mathrm{~g}$ protein concentrate, $40 \mathrm{~g}$ mineral premix (Seleeni-Minera) and $5 \mathrm{~g}$ vitamin premix (Terviemix) per kg. Feeding was carried out according to the age of the animals using a scale from 1.1 to 2.8 feed units/pig/d (FU = 0.7 starch equivalents). The daily portion of ESO was $1.0 \mathrm{~kg}$ wet weight per animal for the first three weeks of the trial and $1.5 \mathrm{~kg}$ from then onwards. Both diets were calculated to give the same amount of net energy per day. The calculated digestible crude protein (DCP) content of the control diet was $132 \mathrm{~g} / \mathrm{kg}$. The DCP content of the test diet declined as the trial advanced, but during the whole trial it was calculated to be $132 \mathrm{~g} / \mathrm{kg}$ on average.

The pigs were weighed at $0,4,8$, and 12 weeks from the beginning of the trial. They were fed to approximately $95 \mathrm{~kg}$ live weight and then slaughtered. At slaughter, the carcass weight and thickness of both back and side fat were measured on cold carcasses. Samples were taken from the longissimus dorsi muscle before the last rib from 10 randomly selected carcasses per treatment. The samples were frozen $\left(-18^{\circ} \mathrm{C}\right)$ to await chemical analysis and organoleptic grading.

\section{Chemical analyses and calculation of feeding value}

The chemical analyses of the feeds and faeces were conducted according to standard procedures (AOAC 1984). Crude fat (CF) was determined after acid hydrolysis. Fresh ESO was analyzed for $\mathrm{pH}$, reducing sugars (SOMOGYI 1945, SALO 1965) and lactic acid (BARKER and SUMMERSON 1941). The DM content of ESO was corrected for the loss of lactic acid in oven drying according to PORTER et al. (1984). The amino acid and mineral analyses of ESO were performed as described by NÄSI (1988).

The apparent digestibility of barley starch was assumed to be 1.00 , while the digestibility coefficients of ESO and SBM were calculated by the regression and difference methods (SCHNEIDER and FLATT 1975). The feeding value of the experimental feeds was calculated as feed units according to SALO et al. (1990) and as metabolizable (ME) and net energy (NE) values according to ANDERSEN and JUST (1983).

The count of total bacteria and coliforms in ESO were determined four times during the growth trial (Valtion maatalouskemian laitos 1981).

\section{Analyses of meat samples}

Frozen samples of the longissimus dorsi muscle were thawed in a cooler for 24 hours and allowed to warm up to room temperature for two hours. The chemical analyses of the meat samples were performed according to standard procedures (AOAC 1984). For organoleptic grading, the longissimus dorsi muscle was cut into $15 \mathrm{~mm}$ thick slices, which were fried at $200^{\circ} \mathrm{C}$ for $1 \mathrm{~min} 40 \mathrm{~s}$ on one side and $2 \mathrm{~min}$ on the other. A test panel graded the fried samples for tenderness, juiciness, taste and colour using a 7 point rating scale (tenderness: 1=very tough, $7=$ very tender; juiciness: $1=$ very dry, $7=$ =ery juicy; taste: $1=$ very poor, $7=$ very good; colour: $1=$ very pale, $7=$ very dark).

\section{Statistical analyses}

The data of the digestibility and nitrogen balance assay were subjected to an analysis of variance using the following model (SNEDECOR and $\mathrm{COCH}$ RAN 1989):

$Y_{i j k}=\mu+A_{i}+P_{j}+T_{k}+e_{i j k}$ 
Table 2. Chemical composition of feeds in Experiment 1.

\begin{tabular}{lrrrrlr}
\hline & ESO & SBM & B & BS & & ESO \\
\hline Dry matter, g/kg & 293 & 892 & 877 & 996 & $\begin{array}{l}\text { Amino acids, g/kg CP } \\
\text { Alanine }\end{array}$ \\
Composition of dry matter, g/kg & & & & & Arginine & 58 \\
Ash & 56 & 62 & 26 & 1 & Aspartic acid & 55 \\
Crude protein & 319 & 492 & 128 & 5 & Cystine & 71 \\
Crude fat & 403 & 72 & 35 & 7 & Glutamic acid & 151 \\
Crude fibre & 23 & 68 & 49 & 8 & Glycine & 86 \\
Nitrogen-free extract & 199 & 306 & 762 & 979 & Histidine & 18 \\
& & & & & Isoleucine & 32 \\
Sugars & 101 & & & & Leucine & 63 \\
Lactic acid & 106 & & & & Lysine & Methionine \\
Minerals, g/kg DM & & & & & Phenylalanine & 16 \\
Calcium & & & & & Proline & 32 \\
Phosphorus & 1.62 & & & & Serine & 62 \\
Magnesium & 3.49 & & & & Threonine & 37 \\
Potassium & 2.64 & & & & Tyrosine & 33 \\
Sodium & 15.30 & & & & Valine & 24 \\
& 5.75 & & & & & 43 \\
\hline
\end{tabular}

ESO $=$ ensiled slaughter offal, SBM = soyabean meal, $B=$ barley, $B S=$ barley starch.

where $\mu=$ overall mean, $\mathrm{A}_{\mathrm{i}}=$ effect of animal $i, \mathrm{P}_{\mathrm{j}}$ $=$ effect of period $j, \mathrm{~T}_{\mathrm{k}}=$ effect of treatment $k$ and $\mathrm{e}_{\mathrm{ijk}}=$ residual error. The degrees of freedom for treatment effects were further partitioned into single degrees of freedom by making orthogonal contrasts as follows: $\mathrm{Cl}=\mathrm{ESO}$ diets vs SBM diets (effect of protein source), $\mathrm{C} 2$ = linear effect of protein level, $\mathrm{C} 3$ = quadratic effect of protein level, $\mathrm{C} 4=$ cubic effect of protein level, $\mathrm{C} 5=$ interaction $\mathrm{C} 1 \times \mathrm{C} 2, \mathrm{C} 6=$ interaction $\mathrm{C} 1 \times \mathrm{C} 3, \mathrm{C} 7=$ interaction $\mathrm{Cl} 1 \times \mathrm{C} 4$. Because there were no significant cubic effects (C4) or their interactions with protein source (C7), these were omitted from the tables.

The data of the growth trial were studied by an analysis of variance using the following model (SNEDECOR and COCHRAN 1989):

$Y_{i j}=\mu+B_{i}+T_{j}+e_{i j}$

where $\mu=$ overall mean, $\mathrm{B}_{\mathrm{i}}=$ effect of block $i, \mathrm{~T}_{\mathrm{j}}=$ effect of treatment $j$ and $\mathrm{e}_{\mathrm{ij}}=$ residual error. The initial weight of a pig was used as a covariate in analyzing weight gain, feed consumption and feed conversion rate. A pen was considered one experimental unit.

\section{Results and discussion}

\section{Experiment 1}

The chemical composition of the feed ingredients in Experiment 1 is given in Table 2. After three days of fermentation, the fermented product had a $\mathrm{pH}$ of 3.80 and contained $106 \mathrm{~g}$ lactic acid and 101 $\mathrm{g}$ reducing sugars $/ \mathrm{kg} \mathrm{DM}$. Although some sugars were left from fermentation, the low $\mathrm{pH}$ and high lactic acid content indicate that ESO was well fermented. The product was in liquid form and had a primarily sour odour.

ESO was found to contain $319 \mathrm{~g} \mathrm{CP} / \mathrm{kg} \mathrm{DM}$, which is less than the values reported for meat meal and meat and bone meal by SALO et al. (1990). The lower CP content partly reflects the addition of sugar beet molasses to the offal. On the other hand, the CF content was exceptionally high, $403 \mathrm{~g} / \mathrm{kg}$ $\mathrm{DM}$, even though part of the fat was removed from the offal before fermentation. The ash content remained low, since the ESO had been made from soft offal. The calcium and phosphorus content of ESO was similar to the values reported for ruminant 
Table 3. Supply of nutrients in Experiment 1.

\begin{tabular}{|c|c|c|c|c|c|c|c|c|c|c|c|c|c|c|}
\hline Diet & 1 & 2 & 3 & 4 & 5 & 6 & 7 & 8 & & \multicolumn{5}{|c|}{ Statistical significance } \\
\hline Protein supplement & ESO-0 & ESO-20 & ESO-40 & ESO-60 & SBM-0 & BM-20 : & BM-40 & BM-60 & SEM & $\mathrm{Cl}$ & $\mathrm{C} 2$ & C3 & C5 & C6 \\
\hline $\mathrm{CP}, \mathrm{g} / \mathrm{kg} \mathrm{DM}$ & 105 & 125 & 145 & 165 & 105 & 125 & 145 & 165 & & & & & & \\
\hline Dry & 077 & 077 & 1961 & 152 & 1978 & 2066 & 2109 & 2080 & 56.4 & NS & NS & NS & NS & NS \\
\hline Organic matter & 1978 & 1971 & 1855 & 2029 & 1884 & 1963 & 2000 & 1971 & 53.2 & NS & NS & NS & NS & NS \\
\hline Ash & 99 & 106 & 106 & 123 & 94 & 103 & 110 & 113 & 3.2 & NS & $* * *$ & NS & NS & NS \\
\hline Crude protein & 215 & 254 & 277 & 344 & 202 & 252 & 297 & 333 & 8.8 & NS & $* * *$ & NS & NS & NS \\
\hline Crude fat & 60 & 114 & 155 & 221 & 56 & 63 & 70 & 73 & 7.3 & ***** & **** & NS & **** & NS \\
\hline Crude fibre & 85 & 86 & 83 & 92 & 81 & 89 & 96 & 99 & 2.3 & $*$ & $* * *$ & NS & $* *$ & NS \\
\hline $\begin{array}{l}\text { Nitrogen-free extract } \\
\text { Amino acids, g/d }\end{array}$ & 1618 & 1518 & 1340 & 1371 & 1545 & 1559 & 1537 & 1466 & 37.6 & $*$ & $* * *$ & NS & * & NS \\
\hline Lysir & 8.1 & 10.0 & 11.2 & 17.2 & & - & 13 & 15.4 & s & - & $* * *$ & NS & $*$ & NS \\
\hline Metl & 3.6 & 4.3 & 4.6 & 5.7 & 3.4 & 4.2 & 4.9 & 5.4 & 0.15 & NS & ****** & NS & NS & NS \\
\hline Cystine & 4.7 & 5.0 & 5.0 & 5.8 & 4.4 & 5.2 & 5.9 & 6.5 & 0.14 & $* *$ & ***** & NS & *** & NS \\
\hline Threonin & 7.5 & 8.8 & 9.5 & 11.8 & 7.0 & 9.0 & 10.8 & 12.3 & 0.30 & NS & **** & NS & NS & NS \\
\hline Isoleucine & 8.1 & 9.3 & 10.0 & 12.3 & 7.6 & 10.0 & 12.1 & 13.9 & 0.31 & $* * *$ & $* * *$ & NS & *** & NS \\
\hline $\mathrm{g} \mathrm{C}^{2}$ & 103 & 122 & 141 & 160 & 103 & 122 & 14 & 159 & 0.03 & NS & **** & NS & NS & NS \\
\hline $\mathrm{g} \mathrm{DM} / \mathrm{kg} \mathrm{W}^{0.7}$ & 103 & 102 & 96 & 107 & 99 & 103 & 104 & 102 & 3.2 & NS & NS & NS & NS & NS \\
\hline
\end{tabular}

$\mathrm{ESO}=$ ensiled slaughter offal, $\mathrm{SBM}=$ soyabean meal. $\mathrm{SEM}=$ standard error of mean. Contrasts: $\mathrm{Cl}=\mathrm{ESO}$ vs. $\mathrm{SBM}$ (effect of protein source), $\mathrm{C} 2$ = linear effect of protein level, $\mathrm{C} 3=$ quadratic effect of protein level, $\mathrm{C} 5=$ interaction $\mathrm{C} 1 \times \mathrm{C} 2, \mathrm{C} 6=$ interaction $\mathrm{Cl}$ x C3. Significances: NS (not significant), * $(\mathrm{p}<0.05),{ }^{* *}(\mathrm{p}<0.01)$, *** $(\mathrm{p}<0.001)$.

Table 4. Apparent digestibility of nutrients and nitrogen balance of diets in Experiment 1.

\begin{tabular}{|c|c|c|c|c|c|c|c|c|c|c|c|c|c|c|}
\hline Diet & 1 & 2 & 3 & 4 & 5 & 6 & 7 & 8 & \multirow{3}{*}{ SEM } & \multicolumn{5}{|c|}{ Statistical significance } \\
\hline Protein suppl & SO-0 & ESO-20 & ESO-40 & ESO-60 & SBM-0 S & M-20 & $\mathrm{M}-40$ & BM-60 & & \multirow[t]{2}{*}{$\mathrm{Cl}$} & \multirow[t]{2}{*}{$\mathrm{C} 2$} & \multirow[t]{2}{*}{$\mathrm{C} 3$} & \multirow[t]{2}{*}{ C5 } & \multirow[t]{2}{*}{ C6 } \\
\hline & 105 & 125 & 145 & 165 & 105 & 125 & 145 & 165 & & & & & & \\
\hline $\mathrm{rg}$ & 351 & 848 & 30 & 26 & 55 & 50 & 1 & 834 & 5 & & & NS & NS & NS \\
\hline & 415 & 455 & 0.469 & 81 & 420 & 444 & 65 & 471 & 36 & NS & & NS & NS & NS \\
\hline act & 737 & 776 & 0.782 & & & & & & & NS & & NS & NS & NS \\
\hline rud & 482 & 620 & 0.670 & 700 & 455 & 479 & 0.509 & 0.506 & 0. & $* * *$ & $* * *$ & $* * *$ & $* * *$ & \\
\hline re & 961 & 0.073 & -0.001 & & & & & & & * & NS & NS & NS & NS \\
\hline - & 1 & 0 & 14 & 8 & 4 & 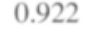 & 0 & 2 & & NS & **** & NS & NS & NS \\
\hline & 34.4 & 40. & 4 & & & & & & & NS & & $\mathrm{N}$ & NS & NS \\
\hline, $\mathrm{g} / \mathrm{d}$ & & 90 & 9.6 & .2 & 8.2 & 9 & & & & NS & & NS & NS & NS \\
\hline te & 14.8 & 16 & & 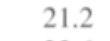 & 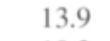 & & & & & " & $*:$ & $\mathrm{N}$ & NS & NS \\
\hline $\mathrm{N}$ re & 10.7 & 2 & 16.4 & & & & & & & NS & & $\mathrm{N}$ & NS & NS \\
\hline- of & 310 & 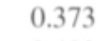 & 361 & 411 & & & & 0.432 & & NS & $* * *$ & $\mathrm{~N}$ & NS & NS \\
\hline hed & 0.420 & 480 & & & & & & & & NS & & NS & NS & NS \\
\hline & & & & & & & & & & NS & $* * *$ & NS & NS & NS \\
\hline Ure & 11.2 & 14.6 & 14.5 & 17.9 & 12.9 & 12.6 & 15.8 & 19.4 & 1.46 & NS & $* * *$ & NS & NS & NS \\
\hline$-\mathrm{g} / \mathrm{l}$ & 6 & 0.72 & 2 & 9 & 65 & 0 & 8 & 0.97 & 0.08 & NS & & NS & NS & NS \\
\hline & & & & & & & & & & 20 & & & No & $1 \mathrm{vo}$ \\
\hline Weight gain, g & 464 & 597 & 771 & 758 & 628 & 636 & 957 & 1007 & 79.3 & & $* * *$ & NS & NS & NS \\
\hline
\end{tabular}

$\mathrm{ESO}=$ ensiled slaughter offal, $\mathrm{SBM}=$ soyabean meal. $\mathrm{SEM}=$ standard error of mean. Contrasts: $\mathrm{Cl}=\mathrm{ESO}$ vs. SBM (effect of protein source), $\mathrm{C} 2$ = linear effect of protein level, $\mathrm{C} 3=$ quadratic effect of protein level, $\mathrm{C} 5=$ interaction $\mathrm{C} 1 \times \mathrm{C} 2, \mathrm{C} 6=$ interaction $\mathrm{Cl}$ x C3. Significances: NS (not significant), ${ }^{*}(\mathrm{p}<0.05), * *(\mathrm{p}<0.01),{ }^{* * *}(\mathrm{p}<0.001)$. 
Table 5. Apparent digestibility of nutrients calculated by regression ( $r$ ) and/or difference (d) methods and feed value of ensiled slaughter offal, soyabean meal and barley in Experiment 1.

\begin{tabular}{|c|c|c|c|c|c|}
\hline & $\mathrm{ESO}(\mathrm{r})$ & $\mathrm{ESO}(\mathrm{d})$ & $\operatorname{SBM}(r)$ & SBM(d) & $B(d)$ \\
\hline Organic matter & 0.811 & 0.833 & 0.849 & 0.895 & 0.832 \\
\hline Ash & 0.731 & 0.791 & 0.823 & 0.886 & 0.419 \\
\hline Crude protein & 0.898 & 0.891 & 0.867 & 0.893 & 0.748 \\
\hline Crude fat & 0.789 & 0.764 & 0.731 & 0.695 & 0.488 \\
\hline Crude fibre & 0.000 & 0.000 & 0.263 & 0.509 & 0.072 \\
\hline Nitrogen-free extract & 1.001 & 0.942 & 0.927 & 0.973 & 0.912 \\
\hline $\mathrm{FU} / \mathrm{kg} \mathrm{DM}$ & 1.662 & & 1.108 & & 1.121 \\
\hline $\mathrm{kg} / \mathrm{FU}$ & 2.06 & & 1.01 & & 1.02 \\
\hline DCP g/kg DM & 287 & & 426 & & 96 \\
\hline $\mathrm{DCP} g / \mathrm{FU}$ & 172 & & 385 & & 85 \\
\hline ME, MJ/kg DM & 21.50 & & 16.29 & & 14.70 \\
\hline NE, MJ/kg DM & 14.25 & & 10.33 & & 9.14 \\
\hline FEs & 1.846 & & 1.389 & & 1.185 \\
\hline
\end{tabular}

$\mathrm{ESO}=$ ensiled slaughter offal, $\mathrm{SBM}=$ soyabean meal, $\mathrm{B}=$ barley. $\mathrm{FU}=0.7$ starch equivalents. $\mathrm{ME}=$ metabolizable energy, $\mathrm{NE}=$ net energy .

offal ensiled with formic acid by MACHIN et al. (1986).

The lysine content of ESO was $47 \mathrm{~g} / \mathrm{kg} \mathrm{CP}$. This value is lower than those listed for meat meal and meat and bone meal by SALO et al. (1990), whereas JUST et al. (1982) have reported values similar to the present results. The methionine, cystine and threonine concentrations found in the present study are in agreement with the values reported for meat and bone meal by JUST et al. (1982) and SALO et al. (1990). According to SKREDE and NES (1988), lactic acid fermentation does not affect the amino acid composition of abattoir waste, which indicates that there is no net synthesis of amino acids by lactobacilli.

The palatability of ESO was good on all levels of supplementation (Table 3). Increasing the level of protein supplementation in the diet led to a linear increase in the digestibility of ash and $\mathrm{CP}(\mathrm{p}<0.001)$ and a linear decrease in the digestibility of organic matter and nitrogen-free extract $(\mathrm{p}<0.001)$ (Table 4). The increase in the apparent digestibility of $\mathrm{CP}$ was similar on both ESO- and SBM-supplemented diets $(\mathrm{p}>0.05)$. There was a quadratic increase in the digestibility of $\mathrm{CF}$ with increasing protein supplementation $(\mathrm{p}<0.001)$. The increase was greater $(\mathrm{p}<0.05)$ for ESO- than SBM-supplemented diets.

The apparent faecal digestibility of CP calculated by the regression method was 0.898 for ESO (Table 5). The value is higher than those reported in literature for meat and bone meal (JUST et al. 1982, KNABE et al. 1989) and fresh slaughter waste (JUST et al. 1982). However, both meat and bone meal and fresh waste had a considerably higher ash content than ESO in the present study, which partly explains their lower digestibility. Furthermore, the ESO was made from soft tissues and soft offal protein is highly digestible, and mild heat treatment has been found to cause only slight damage to protein (HAUGEN et al. 1985). The CP digestibility coefficients reported by SALO et al. (1990) range from 0.84 to 0.92 for meat meal and from 0.82 to 0.84 for meat and bone meal.

The apparent faecal digestibility of CP in SBM determined in the present study $(0.867)$ is in agreement with the results of JUST et al. (1983) and KNABE et al. (1989). 
The $\mathrm{N}$ excretion, $\mathrm{N}$ retention, urea- $\mathrm{N}$ excretion and protein utilization were found to increase linearly with increasing $\mathrm{N}$ intake, as expected $(\mathrm{p}<0.001)$. The increase in $\mathrm{N}$ retention was similar on both ESO- and SBM-supplemented diets $(\mathrm{p}>0.05)$. The $\mathrm{N}$ excretion in urine was higher for ESO- than for SBM-supplemented diets $(\mathrm{p}<.05)$. However, the urea- $\mathrm{N}$ excretion, which gives an indication of the amino acid balance in the diet, was similar on both protein sources ( $p>.05)$. The supply of lysine $(\mathrm{p}<0.05)$, cystine, histidine $(\mathrm{p}<0.01)$, isoleucine and phenylalanine $(\mathrm{p}<0.001)$ was smaller on ESO than SBM diets. Lysine is the first limiting amino acid in barley based diets (FULLER et al. 1979). The calculation of amino acid supply is based on the analyzed levels of amino acids in ESO (Table 3) and the amino acid contents reported by SALO et al. (1990) for soyabean meal and barley.

Daily weight gain increased linearly $(\mathrm{p}<0.001)$ with increasing protein supplementation and was slightly higher for SBM- than for ESO-supplemented diets $(\mathrm{p}<0.05)$. Although the digestibility of $\mathrm{CP}$ was similar for both protein sources, the differences in amino acid supply may have been in part responsible for the poorer performance on the ESOsupplemented diet. However, the recording period may have been too short to show the full performance.

The calculated ME and NE values were 20.28 and $13.33 \mathrm{MJ} / \mathrm{kg}$ DM for ESO and 14.98 and 9.35 $\mathrm{MJ} / \mathrm{kg}$ DM for SBM, respectively (Table 5). Other experiments have given ME values of $15.34 \mathrm{MJ} / \mathrm{kg}$ DM for soyabean meal (JUST et al. 1983), 9.67 $\mathrm{MJ} / \mathrm{kg} \mathrm{DM}$ for meat and bone meal and 11.36 $\mathrm{MJ} / \mathrm{kg}$ DM for fresh slaughter waste (JUST et al. 1982). The considerably higher energy value of ESO compared to meat and bone meal and fresh slaughter waste is due to its high fat and low ash content.

\section{Experiment 2}

In Experiment 2, the average composition of ESO was $301 \pm 18.3 \mathrm{~g} \mathrm{DM} / \mathrm{kg}, 317 \pm 22.6 \mathrm{~g} \mathrm{CP}, 480 \pm 49.7$ $\mathrm{g} \mathrm{CF}$ and $46 \pm 3.9 \mathrm{~g}$ ash $/ \mathrm{kg}$ DM. The content of fat varied the most, from 114 to $534 \mathrm{~g} \mathrm{CF} / \mathrm{kg} \mathrm{DM}$. When the fat content is high, it may limit the use of offal silage in pigs' diets. However, the fat content can be lowered by selection of raw material and by the separation of fat. Fermentation causes the physical separation of oil, liquid and solid fractions (RUSSELL et al. 1992), as also observed in the present study. This is of value in decanting the layer of fat from the top to decrease the fat content and increase the protein content, thus making it possible to increase the proportion of offal silage in the diet.

The total bacteria count ranged from 61000 to $1.1 \times 108 / \mathrm{g}$, which is probably due to the high number of lactobacilli in the product. There were fewer than 10 coliforms/g, which shows the good hygienic quality of the product. No visible surface growth of mould was observed during the oneweek storage on the farm, indicating satisfactory stability of ESO. According to SKREDE and NES (1988) an increasing proportion of bone in slaughter waste reduces the stability of the product. A high fat content can also be critical to the stability of offal silage. Due to fat separation, it is necessary to mix the silage during storage. When oxygen is mixed with the silage it reacts with fatty acids, resulting in a series of reactions called oxidative rancidity. The end products of oxidation have a strong odour and flavour which reduces the palatability of fat (ENSER 1984). A high fat content may also reduce the flow characteristics of offal silage especially at low ambient temperatures.

The performance data for the pigs in Experiment 2 are shown in Table 6 . Two pigs were removed from the control group due to poor appetite. One pig died and five pigs were excluded from the test group for the following reasons: lung infection, tail biting, swine erysipelas and poor appetite (two pigs). No significant differences were observed in daily weight gain and number of days on trial between the control diet and the test diet. However, the protein concentration of the test diet decreased gradually towards the end of the growing period, 
Table 6. Performance, feed consumption and carcass parameters of pigs in Experiment 2.

\begin{tabular}{|c|c|c|c|c|}
\hline & Control & Test & SEM & $\begin{array}{l}\text { Statist. } \\
\text { Signif. }\end{array}$ \\
\hline No. of pigs & 110 & 106 & & \\
\hline Initial weight, $\mathrm{kg}$ & 23.2 & 23.1 & 1.00 & NS \\
\hline Final weight, kg & 98.1 & 97.7 & 0.41 & NS \\
\hline Days on test & 105.1 & 105.0 & 0.56 & NS \\
\hline Live weight gain, g/pig/d & 715 & 711 & 5.2 & NS \\
\hline Total feed, $\mathrm{FU}^{1} / \mathrm{pig}$ & 219 & 220 & 1.6 & NS \\
\hline Feed, FU/pig/d & 2.09 & 2.10 & 0.013 & NS \\
\hline Feed conversion, FU/kg & 2.92 & 2.95 & 0.020 & NS \\
\hline Carcass weight, kg & 73.1 & 73.5 & 0.47 & NS \\
\hline Dressing, \% & 74.5 & 75.2 & 0.18 & ** \\
\hline Back fat, mm & 23.4 & 23.4 & 0.40 & NS \\
\hline Side fat, mm & 15.3 & 14.9 & 0.30 & NS \\
\hline \multicolumn{5}{|l|}{ Longissimus dorsi ${ }^{2}$} \\
\hline \multicolumn{5}{|c|}{ Chemical composition, $\mathrm{g} / \mathrm{kg}$} \\
\hline Water & 753 & 753 & 3.2 & NS \\
\hline Fat & 13 & 14 & 1.0 & NS \\
\hline Protein & 224 & 224 & 3.0 & NS \\
\hline Ash & 12 & 12 & 0.1 & NS \\
\hline \multicolumn{5}{|l|}{ Organoleptic scores ${ }^{3}$} \\
\hline Tenderness & 4.6 & 4.5 & 0.16 & NS \\
\hline Juiciness & 4.3 & 4.6 & 0.14 & NS \\
\hline Taste & 5.0 & 5.0 & 0.09 & NS \\
\hline Colour & 5.5 & 5.4 & 0.19 & NS \\
\hline
\end{tabular}

${ }^{1} \mathrm{FU}=0.7$ starch equivalents.

210 samples per treatment.

${ }^{3}$ Tenderness: $1=$ very tough, $7=$ very tender; Juiciness: $1=$ very dry, $7=$ very juicy; Taste: $1=$ very poor, $7=$ very good; Colour: I=very pale, $7=$ very dark).

SEM=standard error of mean. Significances: NS (not significant), ${ }^{*}(p<0.05),{ }^{* *}(p<0.01),{ }^{* * *}(p<0.001)$.

whereas that of the control diet remained constant. The former feeding strategy may have been more favourable because of the relative reduction in amino acid requirement during the growing period. ESO provided 0.20 of dry matter and 0.22 of feed units of the test diet. All the pigs, except those excluded for the reasons mentioned above, ate the feeds without difficulty and their health remained good throughout the experiment. The total and daily feed consumption of pigs measured as feed units (SALO et al. 1990) and the feed conversion rate were similar on both diets $(\mathrm{p}>0.05)$.

The results obtained in the present study are supported by the observations of MACHIN et al. (1986), who fed growing pigs with different levels of ruminant offal ensiled with formic acid. Their results showed that ruminant offal silage was palatable to pigs and could provide 0.21 of dietary DM without any negative effect on the pigs' performance. However, the carcasses tended to get fatter with an increasing level of offal silage in the diet due to the high energy (fat) content of the product. TIBBETTS et al. (1987) produced poultry offal silage using Lactobacillus acidophilus and successfully fed it to pigs at the rate of 0.20 of dietary DM. Contrary to the present data VAN LUNDEN et al. (1991) found that an increasing level of acid-preserved poultry offal in pigs' diets led to a linear decrease in growth rate due to a decrease in daily feed consumption. In trials, where increasing levels of meat and bone meal replaced soyabean meal in barley based diets, the rate and efficiency of gain of 
growing pigs were depressed, despite the fact that the calculated digestible amino acid supplies remained the same (AlAVIUHKOLA 1989). It has been suggested that either the digestibility coefficients or the values for amino acid content set down in Finnish feed tables (SALO et al. 1990) for meat and bone meal are overestimated.

The dressing percentage was found to be higher for the test diet $(\mathrm{p}<0.01)$. No significant differences were observed in carcass fatness, contrary to the results of MACHIN et al. (1986), or in the chemical composition and organoleptic scores of the longissimus dorsi muscle between the treatments.

In conclusion, the results of this study showed that slaughter offal can be successfully ensiled with sugar beet molasses and lactic acid bacteria, and included in pigs' diets to supply 0.20 of dietary dry matter without any negative effect on the pigs' performance. The protein value of ensiled slaughter offal did not differ from that of soyabean meal.
However, it is necessary to know the amino acid content of the product, especially that of lysine, in order to make adjustments if required. Compared to the drying process, lactic acid fermentation can provide an alternative low-cost method for preserving slaughter offal. A notable feature of ensiled slaughter offal is its high moisture content and, therefore, although drying costs are avoided, transportation costs become considerably high. Thus, the use of the product is restricted to areas close to the production site. Proper storage, preferably airtight silos, are needed on the farm to ensure the stability of the product. Due to its liquid form, the handling of the product is easiest in liquid feeding systems.

Acknowledgements. The authors wish to thank Ms. Gun Söderholm and Mr. Kurt Larsson, who cared for the experimental animals. The financial support of Ab Feora Oy is greatfully acknowledged.

\section{References}

Alaviuhrola, T. 1989. Lihaluurehujauho sikojen rehuna. Lihayhtymän tiedotuslehti 2: 15-16.

ANDERSEN, P.E. \& JusT, A. 1983. Tabeller over foderstoffers sammensætning m.m. kvæg, svin. 102 p. Det kgl. danske Landhusholdningsselskab, København.

AOAC 1984. Official methods of analysis. 1141 p. Association of Official Analytical Chemists, Inc., Arlington, Virginia.

Barker, S.B. \& Summerson, W.H. 1941. The lactic acid in biological material. J. Biol. Chem. 128: 535-554.

Batterham, E.S., Andersen, L.M., Baigent, D.R., Beech, S.A. \& Elııot, R. 1990. Utilization of ileal digestible amino acids by pigs: lysine. Br. J. Nutr. 64: 679-690.

— , Darnell, R.E., Herbert, L.S. \& Major, E.J. 1986. Effect of pressure and temperature on the availability of lysine in meat and bone meal as determined by the sloperatio assays with growing pigs, rats and chicks and by chemical techniques. Br. J. Nutr. 55: 441-453.

Bruyer, D.C., Foulon, M. \& Vanbelle, M. 1990. The amino acid composition of meat and bone meals and its predictability. Arch. Anim. Nutr. 40: 259-265.

ENSER, M. 1984. The chemistry, biochemistry and nutritional importance of animal fats. In: Wiseman, J. (ed.). Fats in animal nutrition. Butterworths, London. pp. 23-51.

Fuller, M.F., Livingstone, R.M., Baird, B.A. \& Atkinson, T. 1979. The optimal amino acid supplementation of barley for the growing pig. 1. Response of nitrogen metabolism to progressive supplementation. Br. J. Nutr. 41: 321-331.

Haugen, E.W., Pettigrew, J.E., Cornelius, S.G. \& Moser, R.L. 1985. Effecs of meat meal manufacturing variations on amino acid bioavailability in pigs. J. Anim. Sci. 61(Supplement 1): 100.

Just, A., Fernández, J.A. \& Jørgensen, H. 1982. Kødbenmels værdi til svin. 525. Beretning fra Statens Husdyrbrugs forsøg. $52 \mathrm{p}$.

- , Jørgensen, H., Fernández, J.A., Bech-Andersen, S. \& ENGGAard HANSEN, N. 1983. Forskellige foderstoffers kemiske sammensætning, fordøjelighed, energi- og proteinværdi til svin. 556. Beretning fra Statens Husdyrbrugs forsøg. $97 \mathrm{p}$.

Knabe, D.A., Larue, D.C., Gregg, E.J., Martinez, G.M., TANKSLEY, T.D., Jr. 1989. Apparent digestibility of nitrogen and amino acids in protein feedstuffs by growing pigs. J. Anim. Sci. 67: 441-458.

Machin, D.H., Silverside, D.E., Hector, D.A. \& Parr, W.H. 1986. The utilization by growing pigs of ruminant offal hydrolysed in formic acid. Anim. Feed Sci. Technol. 15: 273-284.

Moughan, P.J. 1991. Towards an improved utilization of dietary amino acids by the growing pig. In: Haresign, W. \& Cole, D.J.A. (eds.). Recent advances in animal nutri- 
tion 1991. Butterworth-Heineman, Oxford. p. 45-64.

NÄsı, M. 1988. Evaluating barley feed fraction from integrated ethanol-starch production in diets of ruminants. J. Agric. Sci. Finland 60: 701709.

Porter, M.G., Patterson, D.C., Steen, R.W. \& Gordon, F.J. 1984. Determination of dry matter and gross energy of grass silage. In: Gordon, F.J. \& Unsworth, E.F. (eds.). Proceedings of the 7th silage conference. p. 89-90.

Russel., S.M., Fletcher, D.L. \& MerkA, W.C. 1992. Lactic acid fermentation of broiler processing waste: physical properties and chemical analysis. Poultry Science 71: 765-770.

SALO, M.-L. 1965. Determination of carbohydrate fractions in animal foods and faeces. Acta Agric. Fenn. 105: 1-102.

—, TUORI, M. \& KIISKINEN, T. 1990. Rehutaulukot ja ruokintanormit. 70 p. Yliopistopaino, Helsinki.

SChNeIder, B.H. \& Flatt, P.W. 1975. The evaluation of feeds through digestibility evaluation. 423 p. University of Georgia Press, Athens, Georgia.

Shotts, E.B., Jr., Wooley, R.E. \& Dickens, J.A. 1984. Antimicrobic effects of Lactobacillus fermentation on edible waste material contaminated with infected carcasses. Am. J. Vet. Res. 45: 24672470.

SKREDE, A. \& NES, I.F. 1988. Slaughterhouse by-products preserved by Lactobacillus plantarum fermentation as feed for mink and foxes. Anim. Feed Sci. Technol. 20: 287-298.

Snedecor, G.W. \& Cochran, W.G. 1989. Statistical methods. 503 p. 8th ed. Iowa University Press, Ames, Iowa.

Somogyı, M. 1945. A new reagent for the determination of sugars. J. Biol. Chem. 160: 61-68.

Tibbetts, G.W., Seerley, R.W. \& McCampbell, H.C. 1987. Poultry offal ensiled with Lactobacillus acidophilus for growing and finishing swine diets. J. Anim. Sci. 64: 182-190.

Valtion maatalouskemian laitos 1981. C Rehujen laadun aistinvarainen ja mikrobiologinen tutkimus. In: Valtion maatalouskemiallisen laitoksen tutkimusmenetelmät.

Van Lunden, T.A., Anderson, D.M., ST. Laurent, A.-M., BarClay, J. \& Nicholson, J.W.G. 1991. The utilization of acid-preserved poultry offal by growing-finishing pigs. Can. J. Anim. Sci. 71: 935-938.

Wooley, R.E., Gilbert, T.P., Whitehead, W.K., Shotts, E.B., Jr. \& DobBins, C.N. 1981. Survival of viruses in fermented edible waste material. Am. J. Vet. Res. 42: 87-90.

\section{Manuscript received October 1992}

Kirsi Partanen

Matti Näsi

Department of Animal Science

P.O. Box 28

SF-00014 University of Helsinki, Finland

Timo Alaviuhkola

Agricultural Research Centre of Finland

Swine Research Station

SF-05840 Hyvinkää, Finland 


\title{
SELOSTUS
}

\section{Tuoresäilötty teurasjäte lihasikojen valkuaislähteenä}

\author{
Kirsi Partanen, Timo Alaviuhrola ja Matti Näsi \\ Helsingin yliopisto ja Maatalouden tutkimuskeskus
}

Tutkimuksessa selvitettiin tuoresäilötyn teurasjätteen käyttökelpoisuutta valkuaislähteenä lihasikojen ruokinnassa. Pääasiassa elimistä ja ruoansulatuskanavan kudoksista koostuvaa teurasjätettä kuumennettiin autoklaavissa $130{ }^{\circ} \mathrm{C}$ :ssa $30 \mathrm{mi}-$ nuutin ajan. Kuumaan teurasjätteeseen lisättiin $70 \mathrm{~kg}$ sokerijuurikasmelassia per $1000 \mathrm{~kg}$. Seoksen jäähdyttyä siihen lisättiin maitohappobakteerivalmistetta ja sen annettiin käydä ilmatiiviissä siilossa 3 vrk.

Tuoresäilötyn teurasjätteen ravintoaineiden sulavuutta ja valkuaisen hyväksikäyttöä tutkittiin sulavuus- ja typpitasekokeessa, joka tehtiin 8 lihasialla $8 \times 4$ syklisenä jaksokokeena. Sioille syötettiin ohrapohjaisia rehuseoksia, joihin oli lisätty kasvava määrä joko tuoresäilötyn teurasjätteen tai soijarouheen valkuaista. Dieettien raakavalkuaispitoisuudet olivat $105-165 \mathrm{~g} / \mathrm{kg}$ ka.

Valkuaislähteen osuudella dieetissä oli lineaarinen vaikutus ravintoaineiden sulavuuksiin. Raakavalkuaisen sulavuudessa ei ollut eroja valkuaislähteiden välillä, mutta raakarasvan sulavuus oli suurempi teurasjätettä sisältävillä dieeteillä. Tuoresäilötyn teurasjätteen raakavalkuaisen sulavuudeksi saatiin regressiomenetelmällä laskettuna 0,898 ja raakarasvan 0,789 . Korkeasta rasvapitoisuudesta johtuen tuoresäilötyn teurasjätteen energia-arvo oli korkea, 1,66 ry/kg ka. Tuoresäilötty teurasjäte ja soijarouhe olivat lähes samanarvoisia valkuaislähteitä ohrapohjaisilla dieeteillä. Typen pidättymisessä ei ollut eroja valkuaislähteiden välillä. Virtsan typpeä erittyi teurasjätettä sisältävillä dieeteillä enemmän kuin soijarouhedieeteillä, mutta urea- $\mathrm{N}$ erityksessä ei eroa esiintynyt. Tuoresäilöttyä teurasjätettä saaneet siat kasvoivat huonommin kuin soijarouhe dieeteillä olleet siat, mikä todennäköisesti johtui pienemmästä lysiinin saannista.

Kasvatuskokeessa (226 lihasikaa) vilja-tiiviste -ruokintaa verrattiin ruokintaan, jossa osa tiivisteestä korvattiin tuoresäilötyllä teurasjätteellä. Tuoresäilötyn teurasjätteen osuus oli 0,20 rehun kuiva-aineesta. Sikojen kasvussa, rehun kulutuksessa ja rehun hyväksikäytössä ei ollut eroja ruokintojen välillä. Teurastappioprosentti oli suurempi vilja-tiiviste ruokinnalla, mutta silavan paksuudessa sekä longissimus dorsi -lihaksen kemiallisessa koostumuksessa ja aistinvaraisessa laadussa ei ollut eroja ruokintojen välillä. 